\title{
Toll like Receptors (TLRs) expression in HIV children
}

\author{
M Madeshwaran ${ }^{1 *}$, V Gupta ${ }^{1}$, J Chakrabarty², G Narayan ${ }^{3}$, A Kumar ${ }^{1}$ \\ From 2nd International Science Symposium on HIV and Infectious Diseases (HIV SCIENCE 2014) \\ Chennai, India. 30 January - 1 February 2014
}

\section{Background}

Immune activation plays vital role in HIV infection and further progression to AIDS, with TLRs primarily involved in this mechanism.

\section{Methods}

Twenty eight children with HIV in age group of 18 months-14 years attending anti retroviral clinic and 17 healthy children as controls were included in the study. WHO clinical staging, CD4+ count and Toll like receptors (TLRs) 1, 7, 8, 9 expressions from PBMC (peripheral blood mononuclear cells) were studied and correlated with various parameters.

\section{Results}

Mean age of study population was $8.08 \pm 3.41$ years. $75 \%$ of patients were in WHO clinical stage I and II, whereas $25 \%$ in stage III. $29 \%$ HIV children had severe immunosuppression. TLR-1 showed neutral expression in majority (96\%) of HIV children. For TLR-7, 53.5\% HIV children showed upregulation, whereas $32 \%$ and $14.5 \%$ showed downregulation and neutral expression, respectively. TLR-8 expression was downregulated in majority (93\%) of HIV children. TLR-9 was upregulated in $29 \%$ of patients, whereas $71 \%$ had neutral expression. Of all the TLRs studied, only TLR-9 had correlation with WHO clinical stage 3 and severe immunosuppression. No correlation of TLR expression was found with age, nutritional status and ART status of patients.

\section{Conclusion}

Expression pattern of TLR-7 was similar to adult patients with HIV. ART had no effect on expression profile of TLRs. Children with severe immunosuppression had significant up regulation of TLR-9. Similar correlation was not observed with TLR-1, 7 and 8. Altered expression

\footnotetext{
* Correspondence: madhes_kapv@sify.com

C Biomed Central
}

'Department of Pediatrics, IMS, BHU, Varanasi, India

Full list of author information is available at the end of the article pattern of TLR might have implications for disease progression in HIV infection.

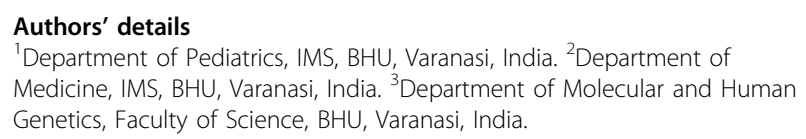

Published: 27 May 2014

\section{doi:10.1186/1471-2334-14-S3-010}

Cite this article as: Madeshwaran et al:: Toll like Receptors (TLRs) expression in HIV children. BMC Infectious Diseases 2014 14(Suppl 3):010.
Submit your next manuscript to BioMed Central and take full advantage of:

- Convenient online submission

- Thorough peer review

- No space constraints or color figure charges

- Immediate publication on acceptance

- Inclusion in PubMed, CAS, Scopus and Google Scholar

- Research which is freely available for redistribution
() Biomed Central (c) 2014 Madeshwaran et al; licensee BioMed Central Ltd. This is an Open Access article distributed under the terms of the Creative Commons Attribution License (http://creativecommons.org/licenses/by/4.0), which permits unrestricted use, distribution, and reproduction in any medium, provided the original work is properly cited. The Creative Commons Public Domain Dedication waiver (http://creativecommons.org/publicdomain/zero/1.0/) applies to the data made available in this article, unless otherwise stated. 